\title{
ARTITRS
}

Università degli Studi di Siena, Siena, Itália.

RICCARDO PUTTI

\section{O IMAGINÁRIO VISUAL DO PÓS-HUMANO: UMA LEITURA ANTROPOLÓGICA ENTRE CINEMA E ARTE CONTEMPORÂNEA}

\section{RESUMO}

o imaginário visual do pós-humano: uma leitura antropológica entre cinema e arte contemporânea. A primeira etapa dessa relação é a definição de pós-humano; isto se concentra particularmente em alguns trabalhos de arte e cinema, tentando reconhecer quais as implicações destes na trama da imaginação coletiva, com referência à dimensão visual de um futuro próximo. 0 estudo prossegue com uma análise do filme Gattaca (1997), dirigido pelo neozelandês Andrew M. Niccol, e os trabalhos de arte Cypher (2009), que contém uma referência explícita ao filme de Niccol, e GFP Bunny/Alba (2000), ambos criados pelo artista Eduardo Kac. Os trabalhos desses dois autores e sua relação entre si tornam-se o principal eixo de

palavras-chave antropologia visual; póshumano; filme de ficção científica; antropologia da arte. referência para a análise da construção de um imaginário das transformações na relação parental e, de maneira mais ampla, nas relações sociais ligadas à revolução genética artificial. 
Neste estudo, pretendo analisar a criação do imaginário do "futuro próximo", usando trabalhos de arte e cinema. Analisarei, especialmente o filme Gattaca, de Andrew Niccol (1997), e os trabalhos de arte Genesis e Cypher, de Eduardo Kac (1999; 2009).

Antes de dar início à verdadeira análise do material visual e de sua importância na construção do imaginário do futuro próximo, explicarei brevemente a perspectiva pela qual ele será analisado. Os dois pontos de fuga dessa perspectiva são, por um lado, o paradigma pós-humano e, por outro, o "imaginário cultural" empregado na produção cinematográfica e na arte contemporânea. Explicarei rapidamente os dois termos: "imaginário" e "pós-humano", e algumas das outras definições às quais farei referência.

Embora o termo e o conceito de imaginário estejam profundamente enraizados na teoria psicanalítica, aqui me referirei ao uso do termo em estudos culturais e, em particular, no trabalho de Graham Dawson e o "imaginário cultural" em seu texto: Soldier heroes: British adventure, empire, and the imagining of masculinities.

"Estas vastas redes interligadas de temas discursivos, imagens, motivos e formas narrativas, publicamente disponíveis em uma cultura a qualquer momento, e que articulam suas dimensões psíquicas e sociais" (Dawson 1994, 48). Esta definição é repetida diversas vezes por autores subsequentes, e particularmente por Susanne Hamscha em The fiction of America (Hamscha 2013).

Logicamente, seria impossível não mencionar Representation: cultural representation and signifying practices, de Stuart Hall trabalho que muito deve às teorias de Jean Baudrillard, Judith Butler e Jacques Derrida.

\section{PÓS-HUMANO}

Embora a expressão "pós-humano" tenha sido usada pela primeira vez no cenário de arte contemporânea, e em literatura há cerca de duas décadas, sua definição semântica ainda é tão vasta que o termo é facilmente confundido.

Embora seja impossível, no tempo que dispomos hoje, abarcar todas as complexas camadas que se fundem ao redor dessa expressão, tentarei, não obstante, fazer um breve relato do termo (com a ajuda de uma relevante bibliografia), a fim de enquadrar a análise do filme de Niccol e dos trabalhos de arte de Kac - ainda que eles não sejam pós-humanos no sentido estrito, mas, sim, exemplos de bioarte.

O termo "pós-humano" também é usado para definir um movimento artístico. $O$ australiano Stelarc e a francesa Orlan tendem a atrair a atenção 
(inclusive dos antropólogos), e estão bem integrados ao grupo de artistas pós-humanos. Provavelmente, como resultados das dimensões "corporais" de seus trabalhos e das tecnologias de exoesqueletos que empregam, esses artistas são decretados membros automáticos do ficcional Cyborg.

A criação da expressão "pós-humanos" pode ser remetida ao marchand americano Jeffrey Deitch, que o usou como título de uma série de exposições das quais foi curador em 1992. Em seu ensaio para o catálogo da exposição Pós-Humano, Deitch (1992) faz referência a um artigo publicado na primeira página do The New York Times, em 6 de fevereiro de 1992, para demonstrar como a cirurgia cosmética e os tratamentos farmacológicos para controle do humor tornaram-se notícias de primeira página, graças a um crescente interesse de um público cada vez maior, na atual capacidade técnica da humanidade de se remodelar. Deitch cria, com alguns traços de caneta, um retrato de uma nova dimensão do eu e da possível reconstrução desse eu a um mundo de distância da hipótese freudiana, e algo não contemplado na teoria da evolução de Darwin.

Curiosamente, nas primeiras linhas do seu ensaio, ao definir "pós-humano", Deitch se refere a um verdadeiro salto evolutivo: "Esta nova fase tecno-evolutiva nos levará para além da eugenia” (., Deitch 1992). Em outras palavras, ele considera uma espécie de salto evolutivo do homo sapiens, resultante da hibridização de corpo e máquina (aqui, pretendo máquina como produto da tecnologia, assim, neste sentido, até uma droga pode ser considerada máquina).

Eis como Deitch descreve o "pós-humano" em uma entrevista a Giancarlo Politi, publicada pela Flash Art:

Tenho a impressão de que estamos começando a passar por uma extraordinária revolução na maneira como os seres humanos se compreendem. A convergência de rápidos avanços em biotecnologia e ciência da computação, com o questionamento da sociedade quanto aos papéis sociais e sexuais tradicionais, podem estar levando a nada menos do que à redefinição da vida humana.

Isso soa um pouco demais como uma má fição científica, mas, na verdade, é provável que poderosas tecnologias da engenharia genética, que permitirão que as pessoas escolham seus filhos, ou sua própria recomposição genética, estejam disponíveis em nosso próprio tempo de vida. A ciência da computação está, talvez, a uma década ou mais de produzir computadores que terão mais capacidade intelectual, e, talvez, até mais inteligência criativa do que qualquer ser humano. 
No ensaio, escrevi sobre o fim da evolução natural e o início da evolução artificial. Esses desdobramentos terão um impacto enorme na economia, na política, e, praticamente, em todos os aspectos da vida. Conforme nos encaminhamos para o século 21, é provável que vivenciemos uma onda de novas tecnologias, e acompanhemos mudanças sociais que, possivelmente, serão ainda mais importantes do que as mudanças que fizeram parte do desenvolvimento da revolução industrial e do modernismo. O objetivo de "Pós-Humano" é começar a observar como essas novas tecnologias e novas atitudes sociais intersectarão com a arte.

Fico fascinado ao pensar em como tantas decisões criativas, e até mesmo artísticas, terão que ser feitas na aplicação das novas biotecnologias e tecnologias da computação. Não estou particularmente envolvido nas últimas conquistas em genética e ciência da computação, obtendo a maior parte da minha informação com jornalistas, e não com fontes originais. Assim sendo, fiquei bastante surpreso quando o artista Paul McCarthy e sua esposa deram-me um artigo do grande geneticista Leroy Hood, intitulado "Notas sobre Futuros Humanos", no qual, usa de fato o termo "pós-humanos". Vindo do campo da crítica de arte, eu, na verdade, estava muito mais próximo da atual teoria sobre genética avançada, do que jamais imaginei (Politi, Kantova, 1992).

Ao tentar entender a genealogia semântica do termo, acho a referência ao artigo de Leroy Hood (1992) particularmente interessante, considerando que o autor é agora um dos principais expoentes da revolução genética (e digital) e da tecnologia que lhe está associada.

Foi no início da década de 1980, que o biólogo americano Leroy Hood aperfeiçoou um sequenciador automático de DNA, um equipamento projetado para mapear com rapidez e automaticamente as sequências das bases de nitrogênio de uma cadeia de DNA.

o sequenciador automático de Hood reduziu dramaticamente o tempo necessário para analisar a sequência nucleotídica de uma cadeia de DNA, possibilitando cumprir em uma única noite o equivalente a uma semana ou mais de trabalho manual sequenciador. Os vários modelos do equipamento, subsequentemente fabricados e comercializados, conseguiram ler doze mil pares básicos por dia, e eram mais precisos do que qualquer tipo de sequenciador manual. Para o objetivo deste estudo, e sem adentrar em demasiados detalhes de como um sequenciador automático de DNA funciona, podemos dizer que uma parte fundamental 
deste instrumento é constituída por um sistema computadorizado complexo, que analisa o resultado, processando-o com incrível rapidez.

Por meio de uma reconstrução filológica do termo "pós-humano", reconstruímos seus elementos essenciais e, mais precisamente, identificamos a ligação entre as duas revoluções ocorridas na segunda metade do século XX (a revolução cibernética e a revolução genética), e como essa ligação cria um cenário onde é possível falar em um salto evolucionário. Dito isso, vale a pena observar um pouco mais de perto esse conceito básico e o trabalho dos autores que o usam para discutir a dimensão social das implicações das teorias pós-humanas.

Entre os autores, cujos trabalhos têm a maior aderência a este texto, encontramos Katherine Hayles, autora de How we became Posthuman (1999). A autora divide a formação do pensamento pós-humano em três fases. A primeira diz respeito ao período entre 1945 e 1960, e tem início com a série Macy Conferences, que levou ao nascimento da cibernética. Norbert Wiener, Claude Shannon, John von Neumann, e Gregory Bateson tiveram um papel fundamental nesse período. Gostaria de enfatizar como - e esta é minha contribuição pessoal -, enquanto segmento do pensamento antropológico, ele está incluído nas origens da cibernética, apesar das críticas em relação aos resultados gerais.

Wiener e Shannon teorizaram que a informação não tinha sentido. Isso exige que a informação seja descontextualizada (o contrário absoluto da personificação). Nem todos concordaram com esse ponto de vista. Donald MacKay, por exemplo, sustentou que a informação deveria ser tratada como algo específico e localizado. Isso significa que a universalização e a quantificação tornam-se quase impossíveis. E, no entanto, prevaleceu a posição de Weiner e Shannon, que acreditavam que a informação é puramente abstrata.

Na segunda fase, entre 1960 e 1985, os principais intérpretes foram Varela e Maturana. A informação é, mais uma vez, algo ligado a um corpo, ao observador. Aqui, gostaria de relembrar brevemente como, desde o início da década de 1920 e do Princípio da Incerteza de Heisenberg, o observador havia sido forçosamente inserido no mundo científico.

Finalmente, a terceira fase, que é a presente (Hayles estava escrevendo em 1999), é caracterizada por vários desdobramentos no campo das formas de vida artificiais. Hayles também introduz uma crítica à visão pós-moderna, que desmonta o corpo. Ela não se surpreende que teóricos que escrevam sobre o corpo prefiram escrever (como Foucault) sobre a universalidade do corpo. Hayles propõe uma interessante distinção entre "corpo" e "personificação", na qual o primeiro é uma forma abstrata idealizada, um conceito coloquial universal. 
A restrição ao texto de Hayle talvez seja a ausência de uma análise da revolução científica, resultante da genética e das tecnologias de manipulação genética que, atualmente - mas também na década de 1990 - superaram a barreira que separa a informação produzida e o mundo biológico.

Atualmente, tendo sido despersonificada, depois de mais uma vez encontrar seu elo com o observador, a informação tornou-se um sistema de hibridização entre o mundo metabólico e o mundo dos elétrons. A informação artificial é inserida na biológica, e a determina, de maneira a se tornar uma parte componente, agindo no nível do sujeito em suas relações sociais - como recontado no filme Gattaca, ou demonstrado nos trabalhos de arte de Kac.

Assim, por mais de uma década, representações de uma sociedade hipotética infiltraram-se no imaginário popular, uma sociedade hipotética na qual a divisão entre o que é considerado cultural e o que é considerado natural desapareceu.

Agora, vamos examinar esses trabalhos com um pouco mais de atenção.

Em 1997, dez anos após a criação do sequenciador automático e oito anos antes do Projeto Genoma chegar a suas conclusões, o diretor neozelandês, Andrew Niccol (1997), produziu seu primeiro filme: Gattaca - the door of the universe (em português, o título do filme foi adaptado para Gattaca - a experiência genética).

Diferentemente de muitos outros filmes de ficção científica, Gattaca não era a adaptação cinematográfica de um livro. Em vez disso, a ideia e o roteiro foram do próprio diretor. Embora amplamente classificada como cyberpunk, observadores mais atentos definiram a obra como pertencente ao subgênero biopunk.

O filme de Niccol chamava-se originalmente The eighth day (O oitavo dia) - o dia seguinte à criação divina -, mas, quando Jaco Van Dormael apresentou um trabalhou com exatamente o mesmo nome no Festival de Cannes de cinema, de 1996, Niccol mudou-o para Gattaca. A escolha do novo título não foi de modo algum casual. Ele contém uma referência oculta ao DNA e, como veremos mais tarde, é novamente usado, anos depois, por um bioartista. As quatro letras que formam o nome "Gattaca" são, na verdade, as usadas para definir as quatro bases nitrogenadas nas sequências de DNA: A - adenina, C - citosina, G - guanina, $\mathrm{T}$ - timina.

Gattaca se passa em um futuro não tão distante, quando o uso da engenharia genética em seres humanos é algo comum, e o DNA exerce um papel-chave na determinação da classe social. Antes que o embrião seja 
implantado no útero, seus componentes genéticos são planejados por meio da seleção das melhores composições genéticas dos pais. Aqueles que nascem naturalmente, chamados em Gattaca de "não-válidos", são destinados ao desempenho dos trabalhos mais servis e relegados a papéis subordinados. Os membros da população geneticamente modificados, ou "válidos", ocupam as posições dominantes, enquanto os nascidos segundo a "natureza" são marginalizados e lhes é negada a possiblidade de acesso às profissões mais prestigiadas.

o protagonista, Vincent Freeman (Ethan Hawke), é um nascido naturalmente. Na verdade, sua concepção não foi produto da engenharia genética. Pouco após o seu nascimento uma análise inicial do seu DNA estabelece não apenas que ele é míope, mas que tem grande probabilidade de desenvolver uma doença cardíaca - condição que reduz consideravelmente as chances de viver muito além dos trinta anos. Por consequência, os pais de vincent decidem conceber um segundo filho, o irmão mais novo de Vincent, Anthony, com a ajuda de uma programação genética. E assim tem início a disputa entre Vincent e Anthony - o nascido naturalmente e o programado, o não-válido e o válido - continuando ao longo da narrativa do filme. A competição de natação entre os dois irmãos resume muito dos temas contidos em Gattaca: o nascimento de um novo tipo de família genética/transgênica, suas contradições e seu estado híbrido e competitivo A existência desses dois mundos muito próximos e, no entanto, muito diferentes dentro da mesma família é a precursora de interações genéticas ainda mais complexas com o mundo externo.

o desejo de Vincent de se tornar astronauta é incompatível com seu status não-válido, bem como com qualquer esperança de alcançar uma alta posição em uma sociedade baseada em segregação genética.

No mundo de Gattaca é impossível escapar a uma condição subordinada, baseada na composição genética; como não-válido, Vincent destina-se à execução dos trabalhos mais servis.

Determinado a seguir seu sonho de infância de se tornar um astronauta, Vincent muda-se para Gattaca, a cidade dos astronautas e das missões espaciais, onde é empregado como faxineiro. Para superar as barreiras sociais criadas pela segregação genética, terá que usar uma estratégia, um disfarce. Assim, Vincent torna-se um "pirata genético" e assume a identidade de outra pessoa: Jerome Morrow.

o geneticamente programado Morrow é um atleta e campeão de natação que, após um acidente (que depois descobrimos não ter sido um acidente), é confinado a uma cadeira de rodas. Sua composição genética fora programada para lhe permitir se tornar um campeão de natação, mas suas 
chances foram destruídas pelas circunstâncias. Durante o filme, descobrimos que o que pareceu ter sido um acidente, na verdade, foi uma tentativa malograda de suicídio, resultado da frustração do atleta por nunca ganhar uma competição, tendo sempre que aceitar um segundo lugar.

Como em todo bom filme pop, a trama desenvolve-se em uma intrincada teia de noir e romance, completada com uma fotografia estilo vintage. 0 elemento noir é representado pelo assassinato de um dos supervisores de voo, pouco antes da primeira missão espacial de Vincent. 0 elemento de romance é introduzido sob a forma de uma história de amor entre o pirata não-válido/genético Vincent e a válida Irene Cassini.

Usando a análise e a informação de DNA de uma base de dados contendo as sequências genéticas de toda a população, um cílio encontrado na cena do crime é identificado como pertencente a Vincent.

Como não-válido, Vincent não deveria ter estado naquela parte de Gattaca, e assim a polícia começa a busca pelo pirata genético cuja aparência física ainda é desconhecida. Para se "tornar" Jerome, Vincent submeteu-se a uma cirurgia para encompridar seus ossos da perna e, assim, alterar sua estatura. Mais do que essa "camuflagem", é evidente que um paradoxo semelhante ao descrito na história de detetive de Edgar Allan Poe, A carta roubada, está em jogo.

De fato, ninguém suspeita de Vincent/Jerome, que continua a perambular pelas ruas de Gattaca, protegido por sua identidade de válido. Segue-se uma série de reviravoltas dramáticas na história, inclusive a história de amor entre Vincent e sua colega válida Irene Cassini, e a descoberta de que o investigador é ninguém mais do que Anthony, o irmão programado de Vincent, que acreditava que ele estivesse morto. Nesse turbilhão de acontecimentos, a identidade de Vincent como não-válido é descoberta tanto por Irene Cassini (que mesmo assim continua a amá-lo) quanto pelo investigador/irmão Antony, que, mais uma vez, é vencido em uma "nova versão" da competição de natação.

Justamente quando parece que Vincent está acabado, a polícia descobre que o supervisor de voo foi morto pelo válido responsável pelo programa espacial (preocupado que o orçamento para os lançamentos espaciais fosse cortado, e seu programa, eliminado), e o caso é encerrado.

Assim, Vincent/Jerome consegue viajar para Titano - com a ajuda e o encorajamento de um médico de Gattaca, que confirma sua identidade como válido (o filho do médico é fã de Vincent). Enquanto Vincent dirige-se para Saturno, o verdadeiro Jerome comete suicídio, deixando sangue e urina suficientes, com os quais Vincent conseguirá provar sua identidade como válido pelo resto da vida. 


\section{O CORPO}

A história pode lidar com os problemáticos assuntos sociais e éticos que giram em torno da relação entre genética e sociedade, mas o objeto implícito do filme é o corpo.

Gattaca é a representação de uma possível distopia social futura, baseada em discriminação genética. Inserido nesse eixo principal, encontramos os temas de rivalidade fraternal, amor entre diferentes classes sociais (o não-válido Vincent e Irene Cassini) e as forças opostas do acaso e da programação.

É o acaso que estabelece as "imperfeições" genéticas resultantes de uma concepção natural, e é o acaso que desorganiza a programação genética do corpo do atleta.

Aparentemente, então, o filme pode ser lido ao longo dessas linhas de narrativa textual, até a explicação de uma visão individualista do protagonista que, por sua própria vontade, afirma sua subjetividade natural. No entanto, vários cúmplices válidos de Vincent deixam a dimensão social escancarada, como uma estrutura comum para superação das barreiras entre as classes genéticas.

A sociedade descrita em Gattaca lembra a visão distópica de Aldous $\mathrm{Hu}-$ xley em Admirável mundo novo, de 1932. No entanto, no livro de Huxley, a programação genética é compulsória, imposta por um Superestado autoritário e controlador. Por outro lado, em Gattaca, o que vemos pode ser definido como eugenia liberal, não é o Estado que decide as diretrizes, e sim os pais que, autonomamente, escolhem as preferências para seu filho.

Além do fio condutor do filme, que descreve a dimensão social, as imagens descrevem outro assunto, complementar e ainda mais evidente do que o entremeado na narrativa; as imagens, de fato, demonstram a centralidade do corpo como lugar de transformação e contraste, como campo concreto da genética - de programação e, ao mesmo tempo, de acaso. O corpo é como o cruzamento de relações sociais e políticas, onde ocorrem tanto a personificação quanto a contradição, o ponto onde a biopolítica não mais foucaultiana torna-se um lugar concreto de manifestação e realização.

\section{SINÉDOQUE}

A primeira sequência do filme mostra, de maneira ampliada, os detalhes de partes residuais do corpo. Mesmo antes do início da narrativa, como pano de fundo para os créditos de abertura, o diretor insere uma sequência que capta vigorosamente a atenção para o corpo e seus 
componentes residuais. Jackie Stacey (2005) fornece uma interpretação interessante dessa sequência inicial em seu artigo:

Na sequência de abertura de Gattaca, uma cena enigmática, de beleza formal minimalista, gradualmente se torna uma exposição do descarte de detritos corporais abjetos, visando um disfarce elaborado. Nas primeiras cenas do filme, o aumento visual excessivo de unhas cortadas, mechas de cabelo e descamação da pele, provoca um engano visual na plateia: as unhas parecem pedaços grandes de vidro fosco em formato de quarto crescente; o cabelo, canos de borracha; a queda de pele, uma linda nevada. Inicialmente inidentificáveis, esses gigantescos fragmentos corporais caem em câmara lenta, atingindo o chão com uma vibração surda, até se assentarem em uma superfície azul luminosa, que preenche a tela (Stacey 2005, 1851).

Aqui podemos dizer que o diretor usa a figura de retórica da sinédoque (uma parte do todo). Unhas, pele e cabelo tornam-se representativos do corpo inteiro. Mais precisamente, personificam a identidade total do indivíduo, sem precisar exibir a totalidade.

Usando essa estratégia retórica, que identifica o corpo usando um de seus segmentos, Gattaca ilustra, ou melhor: descreve, a maneira como as tecnologias genéticas mudaram o conceito de identidade.

A identidade já não é fornecida por uma imagem ou uma fotografia (uma fotografia de passaporte, por exemplo), mas sim pelo que está escondido (como já acontece nos aeroportos onde a imagem da íris é usada para verificação da identidade). Ainda que essa não seja uma novidade absoluta (as impressões digitais foram inventadas no século XIX), em Gattaca isso ocorre em um nível ainda mais infinitesimal. Vamos até as profundezas da célula, até aquela dimensão biológica irredutível do corpo que, não obstante, parece quase nos escapar.

o panóptico, vigilância ótica absoluta, abre caminho para uma espécie de vigilância molecular, realizada por computadores e pela genética, que redefine a observação do corpo, levando-o para o mundo do infinitesimal e subtraindo a validade da certificação.

A vigilância é efetuada com o uso de novos parâmetros de identificação, que já não são confiados à visão, e sim à investigação biológica realizada com instrumentos tecnológicos.

Analises instantâneas de sangue e urina para o sequenciamento de DNA, um cílio como carteira de identidade, fragmentos que fogem ao controle, 
emanações quase incorpóreas do corpo, que distribuem fragmentos que parecem, contudo, conter a total identidade do sujeito.

Aqui, podemos encontrar uma espécie de crítica implícita às teorias foucaultianas de biopoder, como a do texto contemporâneo de Donna Haraway (1997).

Segundo a autora, o mundo tecnológico ao qual Foucault se refere já não existe. A modernidade evoluiu para o pós-humano e as tecnologias de dominação são realizadas com o uso de computador e sistemas genéticos, e não óticos (Ibid.).

Uma imagem. O corpo, crescentemente um terreno para relacionamentos com a máquina, encontra sua identidade através da relação com a própria máquina. Esse aspecto conjecturado por Gattaca é um organismo microscópico muito além do oticamente visível. Na verdade, se o comprimento do DNA humano é pouco maior do que um milímetro, sua largura vai de 2,2 a $2,4 \mathrm{~nm}$.

Por meio dessa referência à invisibilidade do corpo e seu nível "biológico", Gattaca revela o aspecto dual da tecnologia como uma ferramenta de manipulação genética e um sistema de identificação. 0 que o filme demonstra sob a aparência de "vida nua" - para usar a expressão cunhada por Giorgio Agamben (2005) - é, na verdade, uma vida revestida de aparatos técnicos. o corpo, como expressão de uma camada biológica, torna-se palco de um mundo tecnocultural que atua nas profundezas do biológico e o transforma de modo a lhe conferir uma forma bioartificial ou biocyborg.

\section{VISÍVEL/INVISÍVEL}

Nesse diálogo entre o visível e o invisível, Gattaca é, em parte, coerente com a tradição icônica ocidental. o corpo é, de fato, representado durante séculos como o veículo com o qual se revela o invisível. Basta pensar na pintura gótica e na arte sacra, em que, através da imagem do corpo, a divindade invisível torna-se visível. 0 estatuto da imagem que caracteriza a cultura ocidental não foi criado por um filósofo, ou um movimento artístico, e sim fixado no ano de 787 pelos padres reunidos no Segundo Concílio de Niceia, o sétimo concílio ecumênico da Igreja Católica.

O concílio estabeleceu a vitória dos iconófilos sobre os iconoclastas. Esse antigo debate sobre a imagem e as conclusões resultantes e aceitas (em meio a contrastes dramáticos, por toda cristandade) moldaram a cultura ocidental (Russo 1997). Na sequência inicial de Gattaca, mas também no restante do filme, as partes visíveis do corpo são uma referência visível ao DNA invisível. 


\section{HIBRIDIZAÇÃO ALÉM DO CORPO}

Assim, em Gattaca, por um lado, o corpo é definido em sua relação com a tecnologia, por outro, pela necessidade de estabelecer relações com outros corpos - como as entre válidos e não-válidos, entre corpos geneticamente modificados e corpos não programados. Enquanto essa relação é dominada pelo poder, essa dominação tem sua porosidade. Válidos aliados, Victor/Jerome, representam essa porosidade, expressa de diversas maneiras: o ato de se apaixonar, competição/aliança, respeito.

o principal modo pelo qual a porosidade é descrita no filme é o de se apaixonar, que, apesar do ambiente asséptico e tecnológico, consegue descobrir uma forma de fugir à hierarquia social totalitária.

Apaixonar-se, e a habilidade do amor em subverter a ordem estabelecida, tornam-se a estrutura de referência para uma das partes que constituem o enredo de Gattaca. A história de amor entre Vicent e Irene expõe a fragilidade dos limites codificados, com uma explosão do que poderíamos descrever como a capacidade subversiva do erotismo (Bataille 1962).

Em Gattaca, a escolha do(a) companheiro(a) parece depender mais da avaliação dos fatores genéticos do que da "correspondência de sentimentos amorosos", descrita por Foscolo em sua obra Dei sepolcri (1807) como sentimentos amorosos que vão além do racional e constituem, por fim, a incontrolável prerrogativa humana.

Para ser mais claro, gostaria de me referir rapidamente a outros filmes de ficção científica inspirados pela robótica, como Eu, Robô, de Alex Proyas (2004), e O homem bicentenário, de Chris Columbus (1999), com Robin Williams, em que o cyborg é ameaçado pela habilidade humana de sentir emoções.

O elemento de competição/aliança é representado pelo relacionamento entre os dois irmãos e, mais especificamente, pela competição de natação (a natação é um tema recorrente e, na verdade, Vincent adota a identidade de um campeão de natação).

Vincent lembra seu irmão de que tinha capacidade para vencê-lo no momento em que já não pensava na necessidade de guardar energia para a viagem de volta (a competição consistia em cada um chegar ao ponto mais distante no mar, e foi perdida por ele, que retornou primeiro). Assim, Vincent vence porque desafia a morte, adotando um ponto de vista menos racional e, portanto, absolutamente humano. Aqui, também, ter sentimentos por outros é o que diferencia o humano criado naturalmente do humano produzido artificialmente, de acordo com uma engenharia que representa o sucesso aparente da racionalidade pura. 
E, no entanto, o estabelecimento de um diálogo entre corpos humanos e corpos geneticamente transformados identifica a hibridização como veículo para a superação do dualismo e a afirmação do pós-humano.

Em outras palavras, essa aliança (e hibridização) representa a superação da oposição natureza-cultura expressa na superação da oposição não-válido/natureza versus válido/cultura artificial.

Interpretada dessa maneira, a transformação em máquina ilustra e atualiza as relações de poder de um sujeito que já não está preso ao contexto dialético.

A fusão do humano e do tecnológico adquire uma nova combinação transversa, como afirma Braidotti $(2013,100)$ : "Scene da Gattaca sul test del DNA, e scena d'amoreVincent Irena casa mare la gara di nuoto".

\section{O CENÁRIO}

Agora, gostaria de considerar alguns pontos em relação ao contexto em que ocorrem esses acontecimentos. 0 diretor estabelece seu futuro ficcional próximo em um passado recente, criando assim uma espécie de curto-circuito na futuridade da narração. Na realidade, este curto-circuito serve para ilustrar como o que está sendo discutido já aconteceu, ou melhor, como o potencial tecnológico já se efetivou, pelo menos dentro dos laboratórios científicos.

Isso poderia situar Gatacca no gênero steampunk, mas seria uma banalização. Ainda que tenha muitas coisas em comum com o gênero, Gattaca ultrapassa-o com seu ambiente muito peculiar.

Vários elementos-chave vão além da fotografia, para os quais o diretor usou um variado repertório de tons vermelhos e amarelos, tais como o cenário do centro espacial e a escolha dos carros usados no filme.

O centro espacial de Gattaca situa-se no Marin County Civic Center, do arquiteto Frank Lloyd Wright, construído no início da década de 1960. A referência a Wright, conhecido por sua visão romântica do pioneirismo americano e sua visão de uma arquitetura em harmonia com o mundo natural, não é de modo algum causal.

O jogo entre o futuro próximo e o passado recente continua com a escolha dos carros usados no filme, todos versões elétricas de veículos produzidos na década de 1960. Assim, o diretor cria uma imagem do futuro enraizada na década de 1960, época em que as sementes da tecnologia pós-humana foram plantadas, e do nascimento da cibernética e da genética. 
Por fim, uma última observação diz respeito ao uso do esperanto nos avisos oficiais exibidos no centro espacial de Gattaca.

o uso do esperanto - um idioma que nunca nasceu, suspenso entre o passado e o futuro - funciona como contraponto ao uso das letras do DNA para criar o título, ou melhor, para transformar o simbolismo do DNA em uma espécie de linguagem embrionária.

Aqui, me refiro à linguagem no sentido estrito da palavra, não como expressão metafórica, mas sim como a relação entre um significante e um significado definidos arbitrariamente.

Poderia ser dito que a genética penetra na esfera da linguagem, ou, mais precisamente, que ela interrompe a oposição entre natureza e cultura, e que os limites mais profundos desta oposição se desintegram.

As irreduzíveis célula biológica e linguagem cultural se confundem na inscrição que, de algum modo, está presente no título, que usa as abreviações da base de nitrogênio do DNA para criar uma palavra.

Existe um artista brasileiro, atualmente residente em Chicago, que coloca essa relação entre linguagem e DNA no cerne de uma série de trabalhos que ele define como arte transgênica.

Em Cypher, um de seus últimos trabalhos, Kac (2009) faz uma referência explícita ao filme Gattaca. No trabalho, o artista codifica por meio do gene do artista a seguinte mensagem: "A tagged cat will attack Gattaca" (um gato monitorado atacará Gattaca).

A expressão "gene do artista" foi criada pelo próprio Kac e se refere, de maneira bem literal, a um gene criado em laboratório, no qual a sequência de aminoácidos foi definida pelo artista de acordo com sua própria lógica linguística.

Em Cypher, Eduardo Kac preparou um verdadeiro livro transgênico: uma caixa que se abre como um livro e contém um kit para a ativação de uma colônia bacteriana transgênica, da qual o gene do artista é sintetizado para codificar um poema curto. A codificação é, invariavelmente, realizada com o uso das iniciais das quatro bases do nitrogênio: adenina (A), citosina (C), guanina (G), timina (T) (diretamente, e sem recorrer ao Código Morse, como em seu trabalho anterior, Gênesis, sobre o qual discutirei daqui a pouco). As quatro letras são usadas para compor uma frase. 
No entanto, uma vez que não são suficientes para as outras seis letras necessárias, ele adotou o seguinte esquema: a repetição por duas ou três vezes de uma das quatro letras-base, corresponde a uma nova lera. 0 esquema do código é o seguinte:

$$
\begin{aligned}
& \mathrm{E}=\mathrm{TTT} \\
& \mathrm{D}=\mathrm{AA} \\
& \mathrm{K}=\mathrm{CC} \\
& \mathrm{W}=\mathrm{GG} \\
& \mathrm{I}=\mathrm{AAA} \\
& \mathrm{L}=\mathrm{TT}
\end{aligned}
$$

Portanto, o poema é: A tagged cat will attack Gattaca.

Desse processo resulta que o poema e o código se complementam de tal maneira que o código é totalmente essencial ao poema. Ambos estão incluídos no livreto presente no kit, possibilitando, assim, que o espectador descubra essa relação, enquanto acompanha o protocolo que dá vida ao poema. O título manifesta uma relação anagramática entre signo e significado que também faz parte do trabalho (do site do artista).

Cypher é um trabalho de arte que se apresenta como um convite, um chamado para participar de uma série de procedimentos que mesclam arte e poesia, vida biológica e tecnologia, leitura/visão e participação quinestésica. Essa relação do objeto escultórico com o livro é ampliada pelo fato de o título do trabalho estar gravado no dorso da luva e na "capa" (a frente do kit). 0 trabalho pode ficar em uma estante e ser claramente identificado. Ao ser aberto, o observador descobre um kit transgênico completo. A "leitura" do poema é feita pela transformação do E. coli com o DNA sintético fornecido. $O$ ato de leitura é processual. Ao seguir o procedimento especificado, o participante cria um novo tipo de vida, que é, ao mesmo tempo, literal e poético.

Não me estenderei sobre a realização e o significado desse trabalho, e as várias referências internas, como ao filme Gattaca, porque gostaria de apresentar outro trabalho de E. Kac, datado de 1999. Gênesis foi o primeiro trabalho de arte transgênico de Kac, apresentado pela primeira vez de 4 a 19 de setembro no Ars Eletronica, realizado no OK Center for Contemporary Art, em Linz, Áustria.

O trabalho consiste em várias sequências. Na primeira, Kac cria (em um laboratório de biologia genética) o que chama de "gene do artista", que na fase seguinte será inserido numa bactéria E. coli. O "gene do artista" é uma fita de DNA sequenciada propositalmente. No caso do Gênesis, a fita foi sequenciada de maneira a codificar, por meio do uso de um sistema de símbolos, uma passagem do Gênesis da Bíblia. 
A passagem inscrita por Kac no gene do artista diz: "Let man have dominion over the fish of the sea and over the fowl of the air and over every living thing that moves upon the earth" (Que o homem tenha domínio sobre o peixe do mar e sobre a ave do ar, e sobre cada ser vivo que se mova sobre a terra).

Depois de criado, o gene é introduzido em plasmídeos e então inserido nas células da E. coli. Os plasmídeos são fitas circulares de DNA presentes no citoplasma da célula e distinguíveis do DNA cromossômico, podendo se reproduzir independentemente. Além disso, os plasmídeos têm a habilidade de migrar entre as células.

o Gênesis é um trabalho de arte transgênico que explora a relação intrincada entre biologia, sistemas de crença, tecnologia da informação, interação dialógica, ética e internet. 0 elemento-chave da obra é um "gene do artista" criado pela tradução de uma frase do livro bíblico do Gênesis, em código Morse, e pela conversão do código Morse em pares de base de DNA, segundo um princípio de conversão desenvolvido especialmente para este trabalho. 0 código Morse foi escolhido porque, como primeiro exemplo do uso do radiotelegrafo, representa o nascimento da era da informação, a gênesis da comunicação global (Perra 2000, 6-81).

Assim, Kac transpôs basicamente a passagem do Gênesis para Código Morse, de tal maneira que apenas quatro símbolos são usados para codificar sua mensagem. o Código Morse, na verdade, usa cinco símbolos: ponto $(\cdot)$, traço $(-)$, um espaço curto (entre cada letra), um espaço médio (entre palavras) e um espaço longo (entre frases). Nesse caso, considerando que ele estava lidando com uma única frase, Kac usou apenas quatro símbolos.

Obtido o texto em Código Morse, ele associou cada uma das quatro bases nitrogenadas necessárias para codificar uma fita de DNA: adenina (A), guanina ( $\mathrm{G}$ ), timina $(\mathrm{T}$ ) e citosina $(\mathrm{C})$ a um símbolo Morse: o ponto para $\mathrm{C}$, o traço para $\mathrm{T}$, o espaço entre palavras para $\mathrm{A}$, e o espaço entre letras para G. Usando as letras que simbolizam as várias sequências químicas, relacionou o código Morse a uma estrutura de DNA. Conseguida a sequência ordenada de bases de nitrogênio, isso foi produzido bioquimicamente para gerar uma molécula de DNA. Essa molécula foi, então, inserida nos plasmídeos que, por sua vez, foram inseridos nas células da E. coli. 
figura 1

Eduardo Kac, Encrypption stones, granito gravado a laser (díptico), 50 x 75 cm cada, 2001. A configuração triádica das Encryption stones revela criticamente as operações intersemióticas existentes no cerne de nossa compreensão atual dos processos da vida. Coleção Richard Langdale (Columbus, Ohio)
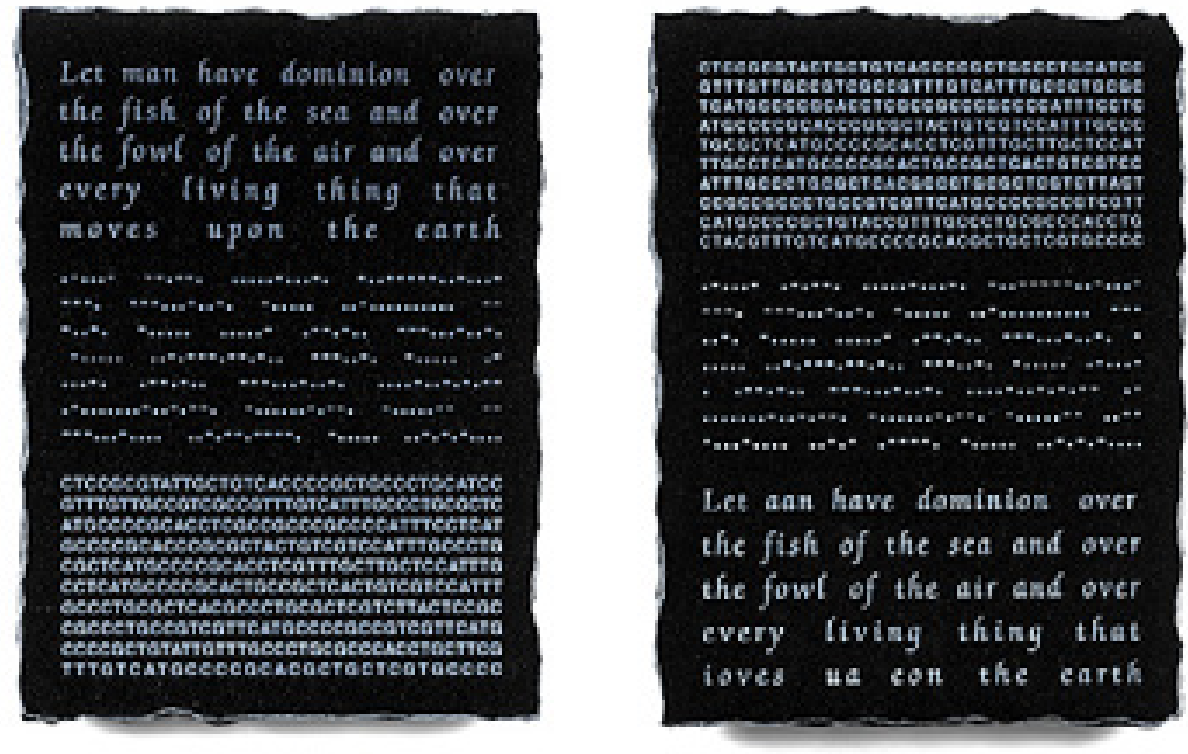

O próximo passo foi marcar as células com uma técnica baseada no gene GFR, em suas duas variantes: ECFP e EYPC. Essencialmente, as células nas quais os plasmídeos eram inseridos com o gene do autor eram marcadas de azul quando expostas à radiação ultravioleta, enquanto as células sem o gene do autor eram marcadas de amarelo quando expostas ao U. V. Isso possibilitou rastrear as mutações e migrações entre as células que trocam os plasmídeos.

Foram gerados três tipos de situações:

1. A bactéria azul (ECFP) troca seus plasmídeos com as amarelas (EYFP). Essa troca produz uma nova bactéria verde (EGFP).

2. Não há troca, portanto, a bactéria conserva sua cor original.

3. A bactéria perde todos os seus plasmídeos e adquire uma cor ocre-claro.

Depois que a cultura de células ficou pronta, Kac desenvolveu um sistema de exposição e interação com o conjunto de bactérias em desenvolvimento. A placa de Petri, na qual a cultura foi colocada, foi observada por uma câmera, cuja imagem era projetada tanto no showroom quanto via web. Além disso, usando uma conexão eletrônica, qualquer visitante virtual podia interagir diretamente com a bactéria. Acendendo uma luz ultravioleta, era possível ver tanto as diferentes cores e estratégias de mutação dentro da colônia quanto acelerar a troca de plasmídeos.

A exposição terminava com a extração da fita de DNA que codificava a passagem bíblica e a verificação de eventuais mutações na sequência de bases de nitrogênio. As mutações eram sempre decodificadas de acordo com o Código Morse.

1. Disponível em: <https://goo.gl/36FtGo>. Acesso em: 8 dez. 2017. 
Segue-se uma das variações resultantes: "Let man have dominion over the fish of the sea and over the fowl of the air and over every living thing that ioves ua eon the earth"2.

Por fim, gostaria de encerrar com a apresentação de outro trabalho de Kac, Alba/GFP Bunny ${ }^{3}$.

De todos os trabalhos de arte transgênica, Alba, a coelha transgênica, foi um dos que provocou maior controvérsia, mesmo antes de ser "exibido". Foi censurado um dia após ser realizado, antes de sair do laboratório de engenharia genética no qual tinha sido realizado. Na verdade, o trabalho deixou de chegar até seu criador, ou até o público em geral.

Alba, cujo nome como trabalho de arte é "GFP Bunny", é - ou, talvez eu deva dizer, era - uma coelha albina muito parecida com qualquer outro coelho: branca, de olhos vermelhos. 0 que diferenciou essa criatura modificada geneticamente foi a maneira como se tornava verde fosforescente, quando exposta a uma fonte de radiação ultravioleta. Tudo mais a respeito do animal era igual à espécie natural, e o efeito fluorescente não alterou de maneira alguma suas funções vitais.

Para obter a fluorescência de Alba, o gene que regula a produção da proteína relativa ao fenômeno da fluorescência na alga Aequorea victoria foi incorporado ao conjunto de genes original.

Para Eduardo Kac, seu complexo projeto de arte Alba/GFP deveria ser o ponto de partida de uma reflexão muito mais ampla sobre a presença de formas de vida transgênica nas sociedades complexas, atualmente tão difundida.

Assim, Eduardo esperava que a inclusão social do seu trabalho desencadeasse discussões sobre engenharia genética e encorajasse uma crítica social sobre técnicas genéticas, crítica que provocaria uma consciência de massa sobre essas tecnologias específicas e, acima de tudo, sobre seu amplo uso nos laboratórios de pesquisa.

O projeto "GFP Bunny", diz Kac, inclui não apenas o processo de trazer Alba ao mundo e integrá-la na sociedade, mas também, deliberadamente, provocar os medos, as fantasias, e as esperanças que temos em relação à genética e às novas formas de vida. Um pequeno salto para Alba; um grande salto para a humanidade (Allmendinger 2001)

2. Disponível em: <https://goo.gl/7L3z3D>. Acesso em: 8 dez. 2017.

3. Disponível em: <https://goo.gl/tbxtuE>. Acesso em: 12 dez. 2017. 
O projeto envolveu três fases: a primeira foi dedicada à criação de um coelho transgênico em um laboratório de pesquisa genética; a segunda envolveu a apresentação do mamífero transgênico ao público; e a terceira veria Alba introduzida na vida doméstica da família de Kac, como animal de estimação transgênico.

Dessa maneira, o artista queria criar um acontecimento social complexo, em que a fase criativa seria seguida por um momento de diálogo, em que o público em geral, juntamente com artistas, escritores, filósofos e cientistas, refletiria sobre as implicações culturais do animal "quimérico” (palavra esta usada, aqui, no sentido mitológico, e não biológico).

De fato, como o próprio artista declara, a arte transgênica de Kac não acaba com a simples criação de um trabalho de arte genético, mas sim procura evoluir para um assunto social transgênico.

o cerne do trabalho do artista brasileiro deveria ser as relações sociais que se desenvolveriam em torno dessa nova forma de animal doméstico. Alba, na verdade, participaria de todas as interações sociais que envolvem um animal doméstico, apenas com o acréscimo da natureza transgênica. Poderíamos acrescentar "animal cultural" a essa fase, provocando, assim, um confronto entre animal e cultural (voltarei a este assunto posteriormente).

A coelha transgênica deveria ser interpretada, segundo a ideia do artista, como uma nova fronteira no relacionamento entre o homem e os animais domésticos. De fato, ele baseou seu pensamento artístico na associação que une as espécies em um relacionamento de coevolução, a ponto que o Homo sapiens atual é capaz de, pelo menos parcialmente, redesenhar o status biológico de outras espécies e, evidentemente, até o seu próprio - se não a nível ético, pelo menos em um nível técnico.

Em seu trabalho artístico, Kac preocupou-se com a reconstrução de pelo menos parte da relação entre as espécies, que por milhares de anos ligou o Sapiens ao Orycotolagus cuniculus, usando referências iconográficas que abrangem das moedas romanas a imagens usadas no calendário asteca. Em outros termos, podemos dizer que, para Kac, a coelha Alba/GRF deveria ter sido um passo além em uma série de relatórios referentes à associação coelho-homem, reduzindo essa relação no cenário tecnológico contemporâneo.

Com esse trabalho, o artista quer fornecer as coordenadas para uma reflexão sobre as transformações que o relacionamento homem/outras espécies está sofrendo, graças à adoção de técnicas de engenharia genética, transformações que, não obstante, deveriam adquirir uma dimensão de crítica social quanto à modificação tecnológica de genomas. 
A primeira parte do trabalho foi, de forma polêmica, executada nos laboratórios do Institut National de Reherche Agronomique (Instituto Nacional de Pesquisa Agrônoma), na França, em colaboração com o pesquisador Louis-Marie Houdebine. As descrições dessa fase são contraditórias.

Enquanto, para Kac, havia uma concordância quanto à operação como um todo, tanto o laboratório quanto o pesquisador negam isso, alegando que Kac meramente estudou um de seus inúmeros animais transgênicos, nunca lhes tendo pedido para criar um coelho GFP especificamente para ele. Em vez disso, ele simplesmente pegou um dos vários coelhos GFP, normalmente criados para propósitos do laboratório, e o usou em seu projeto.

Louis-Marie Houdebine dá a seguinte versão dos acontecimentos: "Os coelhos GFP foram preparados, como sempre dissemos, anos atrás, antes que E. Kac viesse nos visitar. Meu colega, J. P. Renard, pediu-me que gerasse esses coelhos porque precisava de células com identificação para clonar coelhos. Escolhemos construir um gene capaz de expressar o gene GFP em todos os tipos de células. Esperava-se que isso criasse uma ferramenta muito versátil (Boulanger et al., Transgenic Research 2002, 11, p. 88). E "essencialmente, todas as células dos coelhos são verdes sob a luz ultravioleta. Os coelhos recém-nascidos aparecem uniformemente verdes, enquanto não têm pelos. Nos adultos, apenas a parte despelada do corpo aparece verde, e, é claro, os olhos são verdes e não vermelhos (sob luz UV)”’.

A segunda e terceira fase do projeto artístico de Kac nunca foi completada, pelo menos não da forma pretendida inicialmente, devido à proibição que impediu a saída de Alba do laboratório INRA. A apresentação deveria ter ocorrido dentro do AVIGNONumerique, em junho de 2000, mas foi suspensa porque o Institut National de Recherche Agronomique (Instituto Nacional de Pesquisa Agrônoma), ou, em outras palavras, o centro público de pesquisas da França, onde a variação transgênica de "Alba/GFP Bunny" fora produzida, não queria se ver como centro de um escândalo envolvendo a criação de animais transgênicos destinados a um "prazer artístico" ou à pura curiosidade. Acima de tudo, não queria que surgisse especulação quanto ao uso apropriado de verbas públicas.

Na verdade, Alba/GFP Bunny não representa o único experimento referente à criação de um mamífero transgênico fluorescente. Longe disso. De fato, existe uma produção bem consolidada de mamíferos GFP transgênicos, inclusive ratos e porcos, concebidos para experimentos científicos. 0 escândalo de "Alba/GFP Bunny" foi resultado do seu propósito puramente artístico, ou até mesmo lúdico. Realmente, a terceira fase do projeto de Kac previa a inserção do animalzinho transgênico na rotina doméstica.

4. Disponível em: <https://goo.gl/izfRB4>. Acesso em: 8 dez. 2017. 
Kac claramente resume seu ponto de vista ao afirmar:

Sob meu ponto de vista, não há razão para se acreditar que a arte interativa do futuro será semelhante a qualquer coisa que conhecemos no século 20. A "GFP Bunny" (Alba) mostra uma promessa alternativa, e deixa claro que existe um conceito profundo de interação, ancorado na noção de responsabilidade pessoal (tanto quanto ao cuidado, quanto à possibilidade de reação). A "GFP Bunny" dá prosseguimento ao meu foco, dentro da arte, daquilo que Martin Burber chamou de "relacionamento dialogal", Mikhail Bakhtin de "esfera dialógica da existência", Emile Benveniste de "intersubjetividade" e Humberto Maturana de "domínio consensual”: esferas compartilhadas de percepção, cognição, e agência, nas quais dois ou mais seres sensíveis (humanos ou não) podem negociar suas experiências dialogicamente. 0 trabalho também é inspirado pela filosofia de alteridade de Emmanuel Levinas, que afirma que nossa proximidade com o outro exige uma resposta, e que o contato interpessoal com outros é o relacionamento singular de responsabilidade ética. Crio meus trabalhos para aceitar e incorporar as reações e decisões feitas pelos participantes (inclusive bactérias e outras formas de vida) (Bolognini 2006).

Gostaria de concluir chamando atenção para o fato de que, em 2010, Craig Venter (Gibson 2010) anunciou ter criado o DNA de uma célula, graças à elaboração de uma sequência cromossômica, calculada exclusivamente com o uso de computadores. Na verdade, sem o computador, o cálculo de todas as bases do nucleotídeo presentes na fita teria sido impossível. Tão impossível quanto seria, para mim, explicar neste texto o processo de produção de milhões de pares de base a mais para criar este genoma!

Em artigo publicado na revista Science, Gibson explica como foi produzido o genoma da bactéria M. mycoides, com o acréscimo de sequências de DNA para "marcar" o genoma e distingui-lo de um genoma natural (ibid, 52-56). Os cientistas, então, transplantaram o genoma da M. mycoides em outro tipo de bactéria, a Mycoplasma capricolum.

Além disso, considerando que os computadores atuais só conseguem produzir fitas pequenas (e, neste caso, foi necessária uma sequência de mais de um milhão de pares de base), foram empregadas técnicas especiais de montagem, com o uso de enzimas de fitas de DNA. A esta altura, gostaria de expor o aspecto que mais me interessa: "Este é, literalmente, um momento decisivo na relação do homem com a natureza", disse o biologista molecular, Richard Ebright, da Rutgers University, que não estava envolvido no 
projeto. "Pela primeira vez, alguém gerou uma célula totalmente artificial, com propriedades pré-determinadas” (Hotz 2010, on-line).

Poderíamos nos perguntar o que as células que contêm o gene do autor e as que trazem o DNA de um cientista têm em comum, e seria fácil responder com um paradoxo, dizendo que ambas são células culturais. Mas isso, certamente, encobriria a superação da oposição entre natureza e cultura, que, ao simplificar o mundo, nos permitiu traçar uma linha bem definida entre o Homo sapiens e seu ambiente.

\section{REFERÊNCIAS BIBLIOGRÁFICAS}

Agamben, Giorgio. 2005. Homo sacer: il potere sovrano e la nuda vita. Torino: Einaudi.

Allmendinger, Ulli. 2001. One small hop for Alba, one large hop for mankind. New York Arts Magazine, vol. 6, no. 6: Originalmente publicado na New York Arts Magazine 6, no. 6. http://www.ekac.org/ulli.html>, Acessado em 08/06/2018.

Braidotti, Rosi. 2013. The posthuman. Cambridge, UK: Malden Polity.

Bolognini, Maurizio. 2006. Bio-aesthetics and transgenic art: conversation with Eduardo Kac. In Machines, conversations on art and technology, 77-84. Milano: Postmedia.

Dawson, Graham. 1994. Soldier heroes: British adventure, empire and the imagining of masculinities. London, Routledge.

Deitch, Jeffrey (org.). 1992. Post human. Rivoli: Castello di Rivoli Museo d'Arte Contemporanea.

Foscolo, Ugo. 1807. Dei Sepolcri: la genesi.

Gibson, Daniel et al. 2010. Creation of a bacterial cell controlled by a chemically synthesized genome. Science, vol. 329, no. 5987: 52-56.

Hall, Stuart. 1997. Representation: Cultural Representations and Signifying Practices. Front Cover. SAGE Publications.

Hamscha, Susanne. 2013. The fiction of America: performance and the cultural imaginary in literature and film. Frankfurt, New York: Campus.

Haraway, Donna Jeanne. 1997. Modest witness at second millennium: female man meets oncomouse: feminism and technoscience. London, New York: Routledge. 
Hayles, Katherine. 1999. How we became posthuman: virtual bodies in cybernetics, literature, and informatics. Chicago: The University of Chicago Press.

Hood, Leroy. 1992. Speculations about future humans. Engineering \& Science, vol. 55, no. 3: 50-52.

Hotz, Robert Lee. 2010. Scientists create synthetic organism. The Wall Street Journal, 21 maio 2010. Disponível em: <https://goo.gl/G3RgfU>. Acesso em: 7 dez. 2017.

Huxley, Aldous. 1931. Brave New World.

Perra, Daniele. 2000. Eduardo Kac: interview. Tema Celeste, no. 81: 76-81.

Politi, Giancarlo. 1995. It's time for a new vision of contemporary art spaces: interview with Jeffrey Deitch. Flash Art International, vol. 28, no. 180: 55-56.

Politi, Giancarlo e Helena Kontova. 1992. Una straordinaria rivoluzione nel modo in cui gli uomini vedono se stessi. Flash Art, no. 170: Originalmente publicado na Flash Art, n. 170. http://www.flashartonline.it/article/jeffrey-deitch/ accessado em 08/06/2018

Russo, Luigi (org.). 1997. Vedere l'invisibile: nicea e lo statuto dellimmagine. Palermo: Aesthetica.

Stacey, Jackie. 2005. Masculinity, masquerade, and genetic impersonation: Gattaca's queer visions. Signs: Journal of Women in Culture and Society, vol. 30, no. 3: 1851-1879.

\section{REFERÊNCIAS AUDIOVISUAIS}

Columbus, Chris. 1999. O homem bicentenário. Roteiro: Isaac Asimov. Alameda, CA, Estados Unidos, NTSC, cor, 132', DVD.

Kac, Eduardo. 1999. Genesis. Instalação interativa, 1999-1998 (Coleção do Instituto Valenciano de Arte Moderna (IVAM), Valência, Espanha.

Kak, Eduardo. 2001. "Encryption Stones" Collection Richard Langdale. Works from the Genesis series. Access: http://www.ekac.org/genseries.html

Kac, Eduardo. 2009. Cypher. DIY transgenic kit with Petri dishes, agar, nutrients, streaking loops, pipettes, test tubes, synthetic DNA, booklet, $33 \times 43 \mathrm{~cm}$. Rurart Centre for Contemporary Art, Rouillé, France.

Niccol, Andrew. 1997. Gattaca - experiência genética. Roteiro: Andrew Niccol. Culver City, CA, Estados Unidos, NTSC, cor, 106', DVD. 
Proyas, Alex. 2004. Eu, Robô. Roteiro: Jeff Vintar; Akiva Goldsman. Century City, CA, Estados Unidos, NTSC, cor, 115', DVD.

tradução

Elisa Nazarian

revisão técnica

Eduardo Garcia

recebido

07.06 .2015

\section{RICCARDO PUTTI}

Ensina Antropologia Visual na Universidade de Siena e na Escola de Especialização em Patrimônio Antropológico da Universidade de Perugia e dirige o Laboratório de Antropologia Visual "Ars Videndi". Recentemente, com o filme "Direito ao Asilo", ganhou o prêmio Costantino Nigra (2011). Nesse campo trabalhou na comunidade curda de Monte Amiata (Itália), filmando o filme Babylon Caffè (2017). Pesquisa igualmente as implicações antropológicas da relação homem/máquina. Foi curador da exposição: "Nexus human-machine interaciton", Firenze, 2016. Última publicação: A \& A. Sconfinamenti tra Antropologia e Arte Contemporânea, 2017 (livro organizado com M. Carniani). 